\title{
Treatment of gummy smile using botulinum toxin: a review
}

\author{
Yangho Myung, Keoncheol Woo, Seong Taek Kim* \\ Department of Orofacial Pain and Oral Medicine, Yonsei University College of Dentistry, Seoul, Republic of Korea
}

\begin{abstract}
A beautiful smile is made when it is symmetrical and gums are displayed less than 2 - $3 \mathrm{~mm}$. Excessive gingival display also known as "gummy smile" is often recognized to be unaesthetic. Causes of gummy smile can be caused by delayed eruption, vertical maxillary excess, hypermobile upper lip, or a short upper lip. Meanwhile botulinum toxin which is an exotoxin produced from Clostridium botulinum, works by blocking the release of acetylcholine from the cholinergic nerve end plates leading to inactivity of the muscles. The application site and weakens the muscle tone is drawing attention as a gummy smile treatment caused by hypermobile upper lip. There have been many studies about the method of injecting botulinum toxin into muscles around the lips, but there is still no standardized research method and treatment method, so there is controversy over the therapeutic effect. The aim of this study is to review the previous studies about the predictors of indication and effects of gummy smile treatment using botulinum toxin injection. Especially we tried to propose a protocol for optimal dose and efficient injection point through the anatomical considerations for gummy smile treatment using botulinum toxin. (J Dent Rehabil Appl Sci 2021;37(2):61-72)
\end{abstract}

Key words: gummy smile; lip; botulinum toxin; cosmetic; aesthetic; gingivectomy

\section{Introduction}

A person's beautiful smile is probably the most pleasing and meaningful facial expression. Beautiful smile is symmetric and display less than $2-3 \mathrm{~mm}$ of gingiva. Displaying more than $3 \mathrm{~mm}$ of gingiva on smiling is called "gummy smile", which is perceived as aesthetic disorder. Gummy smile may result from delayed eruption, vertical maxillary excess (VME), hypermobile upper lip (HUL), or a short upper lip. ${ }^{1}$ Various treatment modalities have been tried till date for the treatment of gummy smile. Delayed eruption is treated by esthetic crown lengthening. ${ }^{2}$ In case of VME, gummy smile is often treated alone by orthognathic surgery or a multidisciplinary approach with either orthognathic surgery, orthodontic treatment,

*Correspondence to: Seong Taek Kim

Professor, Department of Orofacial Pain and Oral Medicine, Yonsei University College of Dentistry, Yonsei-ro 50-1, Seodaemun-gu, Seoul, 03722, Republic of Korea

Tel: +82-2-2228-3110, Fax: +82-2-393-5673, E-mail: k8756050@yuhs.ac

Received: February 16, 2021/Last Revision: April 2, 2021/Accepted: April 27, 2021 periodontal treatment, or restorative dentistry is required. ${ }^{3}$ In case of short upper lip, it can be treated by lip lengthening, which has also been performed in conjunction with rhinoplasty. ${ }^{4,5}$

In case of HUL, various treatment approaches have been used, with highly variable outcomes. Botulinum toxin (BoNT) type $\mathrm{A},{ }^{6,7}$ lip repositionin, ${ }^{2}$ detachment of lip muscle ${ }^{8}$ and lip repositioning combined with gingivectomy ${ }^{9}$ are the reported treatment approaches.

Of these various treatment approaches of gummy smile, BoNT injection is a relatively simple, noninvasive, less adverse-effective, and reversible treatment approach, drawing a lot of attention. BoNT is a natural protein produced by the anaerobic bacterium Clostridium botulinum, which inhibits the release of 
acetylcholine, a neurotransmitter responsible for the activation of muscle contraction and gland secretion. It blocks the muscle contraction of the application site, weakening the muscle tone. ${ }^{10}$ There are several subtypes of BTX, and BTX-A has been approved for cosmetic use due to its clinical safety and effectiveness. ${ }^{11}$ There have been many studies since Polo ${ }^{6}$ first introduced the method of injecting BoNT into muscles around the lips, but since it was introduced relatively recently, there is still no standardized research method and treatment method, so there is controversy over the therapeutic effect.

Accordingly, the purpose of this study is to provide a summary of treatment method and effects of gummy smile treatment using BoNT injection through literature review and provide a road map for studies on gummy smile treatment using BoNT in the future.

\section{Materials and Methods}

This review included all studies related to the treatment of gummy smile with BoNT injection. The search period is from 1966 to August 2020. Online literature review was conducted via PubMed/MEDLINE, Scopus, and Web of Science on September $1^{\text {st }}$ of 2020 . We considered all available prospective studies, retrospective studies, case series, case reports, and expert reviews. Twelve keywords were used. The keywords were combination of gummy smile OR gingival exposure OR gingival display AND botulinum OR botox OR onabotulinumtoxinA OR abobotulinumtoxinA. Thorough analysis was conducted for searched literatures. The inclusion criteria were prospective clinical studies that included: individuals with excessive gingival display as the main complaint; the BoNT dose and injection point specified; a description of the results obtained in millimeters or percentages; and a follow-up of at least three months after treatment reported. The exclusion criteria were as follows: if BoNT injection was used in combination with other treatment methods, if the BoNT injection method was not provided, the follow-up period was not presented or shorter than three months. (Fig. 1)

The selected literatures were analyzed by the fol-

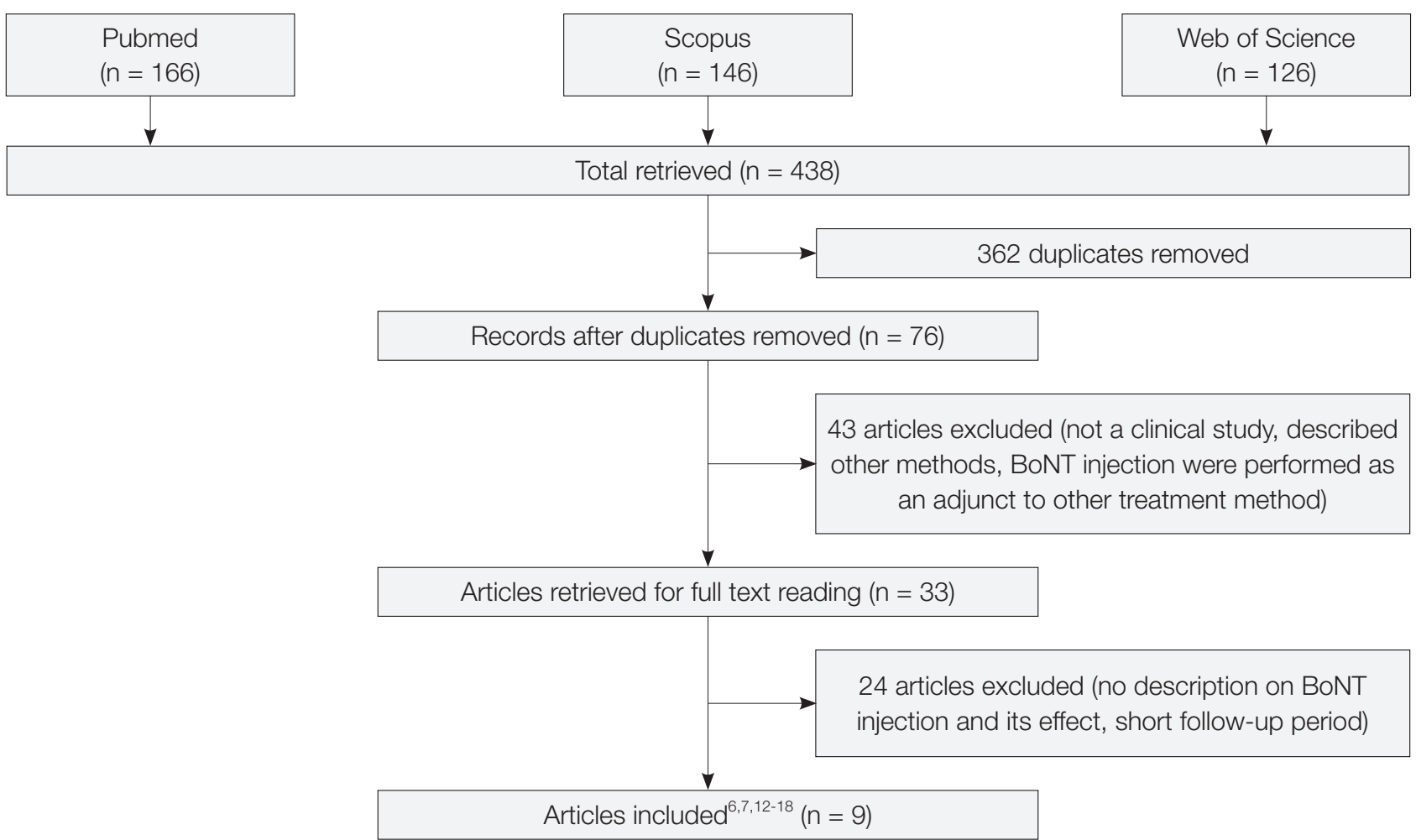

Fig. 1. Flow diagram of the study selection process. 
lowing items-gender and age of patients, measuring site and measuring method of gummy smile, product and preparation of botulinum toxin used in the treatment, target muscle and injection point used in the treatment, pre-treatment gingival exposure, post-treatment gingival exposure, improvement percentage, satisfaction evaluation, short term adverse events, treatment longevity.

\section{Results}

Seventy-six papers were acquired as a result of online literature search via Pubmed, Scopus, and Web of science. Sixty-seven papers among them were excluded as it fell under the exclusion criteria. Fourtythree papers were either described other treatment methods (surgery or laser or filler), not a clinical study, BoNT injection were performed as an adjunct to other treatment method. Twenty-four papers were either no description on BoNT injection and its ef- fect, and short follow-up period. Therefore, 9 papers were used for this review.

Number of subjects who received BoNT injection treatment in 9 papers was 234 in total. When disregarding the 3 papers which do not present either sex or age of the treatment subject, most of treatment subjects was female with a wide range of age distribution from 15 - 70. Eight papers have described the treatment subject selection criteria for BoNT injection and 5 papers considered pure HUL patients as the subject excluding patients with VME and delayed passive eruption of teeth (Table 1).

In regards to the measurement parts for quantity of gummy smile, it was mostly measured at the central incisor. It sometimes was measured at the canine teeth or the first premolar. As a method to measure the quantity of gummy smile, 7 literatures conducted indirect measurement with the use of photograph or video equipment and 1 literature conducted repetitive measurement by putting a ruler directly to the face.

Table 1. Summary of measuring method in the treatment of excessive gingival display

\begin{tabular}{|c|c|c|c|c|c|}
\hline Study & $\begin{array}{l}\text { Number } \\
\text { of patients }\end{array}$ & Measuring method & \multicolumn{2}{|c|}{ Measuring site } & $\begin{array}{l}\text { Evaluation or } \\
\text { inducement of } \\
\text { maximum smile }\end{array}$ \\
\hline Polo, $2005^{6}$ & 5 & Photograph & \multicolumn{2}{|c|}{ Central incisor } & Not presented \\
\hline Polo, $2008^{12}$ & 30 & $\begin{array}{l}\text { Photograph, } \\
\text { video recording }\end{array}$ & \multicolumn{2}{|c|}{ Central incisor } & Extremely funny joke \\
\hline \multirow{4}{*}{$\begin{array}{l}\text { Mazzuco and } \\
\text { Hexsel, } 2010^{7}\end{array}$} & 3 & \multirow{4}{*}{ Photograph } & Anterior GS & Central incisor & \multirow{4}{*}{ Not presented } \\
\hline & 7 & & Posterior GS & First premolar & \\
\hline & 3 & & Mixed GS & Central incisor & \\
\hline & 3 & & Asymmetric GS & First premolar & \\
\hline $\begin{array}{c}\text { Sucupira and } \\
\text { Abramovitz, 2012 }\end{array}$ & 52 & Photograph & \multicolumn{2}{|c|}{ None } & Not presented \\
\hline Singh et al., $2014^{14}$ & 3 & Photograph & \multicolumn{2}{|c|}{ Central incisor } & Not presented \\
\hline Suber et al., $2014^{15}$ & 14 & $\begin{array}{l}\text { Standardized } \\
\text { measuring tape }\end{array}$ & \multicolumn{2}{|c|}{$\begin{array}{l}\text { Right and Left central incisor, } \\
\text { Right and Left canine }\end{array}$} & $\begin{array}{l}\text { Funny joke or } \\
\text { statement }\end{array}$ \\
\hline Al Wayli, 2019 & 45 & Not presented & \multicolumn{2}{|c|}{ Central incisor } & Not presented \\
\hline Cengiz et al., $2020^{17}$ & 28 & $\begin{array}{l}\text { Photograph Standardized } \\
\text { measuring tape }\end{array}$ & \multicolumn{2}{|c|}{ Central incisor } & Funny video clip \\
\hline Hexsel et al., $2020^{18}$ & 41 & $\begin{array}{c}\text { Photograph, Standardized } \\
\text { measuring tape }\end{array}$ & \multicolumn{2}{|c|}{ Central incisor } & $\begin{array}{l}\text { Rest and smiling } \\
\text { naturally }\end{array}$ \\
\hline Total & 234 & & & & \\
\hline
\end{tabular}

GS, gummy smile. 
Also, in order to acquire maximal smile during the process of measuring the quantity of gummy smile, 3 papers described that funny joke or video clip was used (Table 1).

Method to measure the degree of gingival exposure is as important an item as maximal smiling induction. Eight among 9 papers described about methods to measure the degree of gingival exposure. Seven papers measured the degree of gingival exposure through photography, Polo ${ }^{12}$ used photography and video together and Cengiz et al. ${ }^{17}$ and Hexsel et al. ${ }^{18}$ used photography and standardized measuring tape. Suber et al. ${ }^{15}$ conducted 4 repeated measurements with the use of standardized measuring tape without taking a photo and it was because the moment of maximal smile emergence cannot accurately be taken with a photo. As it was mentioned by Suber et al., ${ }^{15}$ it is difficult to capture maximal smiles from a single moment of time. Therefore, the maximal smile screenshots acquired from video can be used as more objective data compared to photography. Also, the studies by Mazzuco and Hexsel ${ }^{7}$ and Polo ${ }^{6}$ and Cengiz et al. ${ }^{17}$ and Hexsel et al., ${ }^{18}$ the effort was made to narrow down the error between before and after treatment using a computer program or reference point to compensate the error that generates from photography at the same environment. It would also be an item to be considered when conducting studies in the future.

Seven studies used onabotulinumtoxinA (Botox, Allergan, Irvine, California) with concentration raging from $2 \mathrm{U} / 0.1 \mathrm{~mL}$ to $5 \mathrm{U} / 0.1 \mathrm{~mL}$. Two studies used abobotolinumtoxin A (Dysport, Ipsen Biopharm Limited, Wrexham, United Kingdom) with a concentration of $25 \mathrm{U} / 0.1 \mathrm{~mL}$. The total dose of BoNT injected per side ranged from 1.95 to $6.25 \mathrm{U}$ and from 2.5 to $7.5 \mathrm{U}$ for onabotulinumtoxin $\mathrm{A}$ and abobotulinumtoxinA, respectively (Table 2).

The number of injection points varies from 1 to 3 per side. Target muscle was distinguished as containing levator labii superioris alaque nasi (LLSAN) and not. In the 7 literature, it was injected only into LLSAN or accompanied by another muscle, and in the 2 literature, it was injected into zygomaticus major $(\mathrm{ZM})$ and zygomaticus minor (Zmi) or orbicularis oris $(\mathrm{OO})$. The other muscles that were injected with LLSAN were ZM, Zmi, levator labii superioris (LLS), depressor setpi nasi (DSN).

In order to determine the location of injection, 2 papers used electromyography, 6 used the distance from particular landmark, and 1 pinpointed the location by touching the contracted muscle during smile to ensure precise muscle location before injection (Table 2).

In all 9 papers, LLSAN is consistently injected muscle. In the 9 literature, it was injected only into LLSAN or accompanied by ZM, Zmi, LLS, DSN. In the 2 of 9 literature, LLSAN was excluded and injected into $\mathrm{ZM}$ and $\mathrm{Zmi}$ for improving the posterior gummy smile or was injected into OO for comparative research with LLSAN. The LLSAN originates from the frontal process of the maxilla and inserts into the upper lip and the skin tissue or the ala of the nose. ${ }^{19}$ Pessa $^{20}$ established the fact that the LLSAN is responsible for the formation of the medial portion of the nasolabial fold and is minimally responsible for the elevation of the upper lip and smile formation. This author also found that the ZM and $\mathrm{Zmi}$ muscles are primarily responsible for the production of the smile. Rubin et al. ${ }^{21}$ concluded that the LLS, the $\mathrm{ZM}$, and the superior fibers of the buccinator muscles under the nasolabial fold are responsible for the production of a full smile. Polo ${ }^{6,12}$ stated that elevate the upper lip during smile is a simultaneous contraction of LLSAN, LLS, ZM, Zmi together with the risorius muscles, and those associated with the lower lip and inserting into the lower portion of the orbicularis oris (OO) muscle are responsible for producing a smile. From the studies by Sucupira and Abramovitz ${ }^{13}$ and Mazzuco and Hexsel $^{7}$ which injected BoNT to LLSAN muscle only, the improvement quantity of gummy smile was $84 \%$ and $96 \%$. From the study by Mazzuco and $\mathrm{Hexsel}^{7}$ which injected BoNT in ZM and Zmi muscle excluding LLSAN, the improvement quantity of gummy smile was $61.1 \%$ and $71.9 \%$. This entails that LLSAN is an important target muscle in BoNT injection. As it was mentioned in the study by Mazzuco and Hex$\mathrm{sel}^{7}$, however, the improvement in posterior gummy smile maybe difficult with LLSAN injection only as 
Table 2. Summary of BoNT injection technique in the treatment of excessive gingival display

\begin{tabular}{|c|c|c|c|c|c|c|c|}
\hline Study & $\begin{array}{l}\text { Product and } \\
\text { preparation }\end{array}$ & \multicolumn{2}{|c|}{ Units per side $(\mathrm{U})$} & \multicolumn{2}{|c|}{ Target muscle } & $\begin{array}{l}\text { Injection } \\
\text { point } \\
\text { (per side) }\end{array}$ & $\begin{array}{c}\text { Determination of } \\
\text { injection point }\end{array}$ \\
\hline Polo, $2005^{6}$ & $\begin{array}{c}\text { Botox } \\
2.5 \mathrm{U} / 0.1 \mathrm{~mL} \\
\text { (OnabotulinumtoxinA) }\end{array}$ & \multicolumn{2}{|c|}{$5-6.25 \mathrm{U}$} & \multicolumn{2}{|c|}{$0 \mathrm{~mm}$} & 2 or 3 point & EMG \\
\hline Polo, $2008^{12}$ & $\begin{array}{c}\text { Botox } \\
2.5 \mathrm{U} / 0.1 \mathrm{~mL} \\
\text { (OnabotulinumtoxinA) }\end{array}$ & \multicolumn{2}{|c|}{$5 \mathrm{U}$} & \multicolumn{2}{|c|}{$0.09 \mathrm{~mm}$} & 2 point & Manual* \\
\hline \multirow{4}{*}{$\begin{array}{l}\text { Mazzuco and } \\
\text { Hexsel, } 2010^{7}\end{array}$} & \multirow{4}{*}{$\begin{array}{c}\text { Dysport } \\
25 \mathrm{U} / 0.1 \mathrm{~mL} \\
\text { (AbobotulinumtoxinA) }\end{array}$} & Anterior GS & 2.5 or $5 \mathrm{U}$ & Anterior GS & LLSAN & 1 point & $\begin{array}{l}1 \mathrm{~cm} \text { lateral and } \\
\text { below the nasal } \\
\text { ala }\end{array}$ \\
\hline & & Posterior GS & $5 \mathrm{U}$ & Posterior GS & $\mathrm{ZM}, \mathrm{Zmi}$ & 2 point & 2 injection point* \\
\hline & & Mixed GS & $\begin{array}{l}6.25 \mathrm{U} \text { or } \\
7.5 \mathrm{U}\end{array}$ & Mixed GS & $\begin{array}{l}\text { LLSAN, } \\
\text { ZM, Zmi }\end{array}$ & 3 point & $\begin{array}{c}\text { Both anterior GS } \\
\text { and posterior GS } \\
\text { injection points }\end{array}$ \\
\hline & & $\begin{array}{l}\text { Asymmetric } \\
\text { GS }\end{array}$ & $\begin{array}{l}5 \mathrm{U} \text { onside } \\
\text { and } 2.5 \mathrm{U} \\
\text { on the other }\end{array}$ & $\begin{array}{l}\text { Asymmetric } \\
\text { GS }\end{array}$ & $\mathrm{ZM}, \mathrm{Zmi}$ & 2 point & $\begin{array}{l}\text { Posterior GS } \\
\text { injection points }\end{array}$ \\
\hline $\begin{array}{l}\text { Sucupira and } \\
\text { Abramovitz, } \\
2012^{13}\end{array}$ & $\begin{array}{c}\text { Botox } \\
3.1 \mathrm{U} / 0.1 \mathrm{~mL} \\
\text { (OnabotulinumtoxinA) }\end{array}$ & \multicolumn{2}{|c|}{$1.95 \mathrm{U}$} & \multicolumn{2}{|c|}{ LLSAN } & 1 point & $\begin{array}{l}3 \text { to } 5 \mathrm{~mm} \text { lateral } \\
\text { to the nostril }\end{array}$ \\
\hline $\begin{array}{l}\text { Singh et al., } \\
2014^{14}\end{array}$ & $\begin{array}{c}\text { Botox } \\
5 \mathrm{U} / 0.1 \mathrm{~mL} \\
\text { (Onabotulinumtoxin })\end{array}$ & \multicolumn{2}{|c|}{$3 \mathrm{U}$} & \multicolumn{2}{|c|}{ LLSAN, DSN } & 2 point & EMG \\
\hline $\begin{array}{l}\text { Suber et al., } \\
2014^{15}\end{array}$ & $\begin{array}{c}\text { Botox } \\
2 \mathrm{U} / 0.1 \mathrm{~mL} \\
\text { (Onabotulinumtoxin } \mathrm{A})\end{array}$ & \multicolumn{2}{|c|}{$4-6 U$} & \multicolumn{2}{|c|}{ LLSAN, LLS } & 3 point & 3 injection point* \\
\hline $\begin{array}{l}\text { Al Wayli, } \\
2019^{16}\end{array}$ & $\begin{array}{c}\text { Botox } \\
2 \mathrm{U} / 0.1 \mathrm{~mL} \\
\text { (Onabotulinumtoxin } \mathrm{A})\end{array}$ & \multicolumn{2}{|c|}{$1.95 \mathrm{U}$} & \multicolumn{2}{|c|}{ LLSAN, LLS, Zmi } & 1 point & Yonsei point* \\
\hline \multirow[b]{2}{*}{$\begin{array}{l}\text { Cengiz et al., } \\
\qquad 2020^{17}\end{array}$} & & Group 1 & $2.5 \mathrm{U}$ & \multicolumn{2}{|c|}{ LLSAN } & 1 point & $\begin{array}{l}\text { Most superior } \\
\text { point of } \\
\text { nasolabial fold }\end{array}$ \\
\hline & $\begin{array}{c}\text { Botox } \\
2 \mathrm{U} / 0.1 \mathrm{~mL} \\
\text { (Onabotulinumtoxin } \mathrm{A})\end{array}$ & Group 2 & $1.25 \mathrm{U}$ & \multicolumn{2}{|c|}{$\mathrm{OO}$} & 1 point & $\begin{array}{c}5 \mathrm{~mm} \text { inferior to } \\
\text { the central and } \\
\text { most inferior } \\
\text { point of the } \\
\text { nostrils }\end{array}$ \\
\hline $\begin{array}{l}\text { Hexsel et al., } \\
2020^{18}\end{array}$ & $\begin{array}{c}\text { Dysport } \\
25 \mathrm{U} / 0.1 \mathrm{~mL} \\
\text { (Abobotulinumtoxin } \mathrm{A} \text { ) }\end{array}$ & \multicolumn{2}{|c|}{$2.5 \mathrm{U} / 5 \mathrm{U} / 7 \mathrm{U}$} & \multicolumn{2}{|c|}{ LLSAN, Zmi } & 1 point & $\begin{array}{l}\text { Nasolabial fold, } \\
1 \mathrm{~cm} \text { below the } \\
\text { alar nasii }\end{array}$ \\
\hline
\end{tabular}

GS, gummy smile; LLSAN, levator labii superioris alaque nasi; LLS, levator labii superioris; ZM, zygomaticus major; Zmi, zygomaticus minor; DSN, depressor setpi nasi; OO, orbicularis oris; EMG, electromyographic guidance.

Manual*, determined by muscle animation (smiling) and palpation on contraction; 2 injection point*, (1) nasolabial fold, at the point of greatest lateral contraction during the smile (2) $2 \mathrm{~cm}$ lateral to the first point, at the level of the tragus; 3 injection point*, (1) $2 \mathrm{~mm}$ lateral to the alar-facial groove (2) $2 \mathrm{~mm}$ lateral to the first injection (3) $2 \mathrm{~mm}$ inferior and between the first $2 \mathrm{~mm}$ sites; Yonsei point*, $1 \mathrm{~cm}$ lateral to the ala horizontally and $3 \mathrm{~cm}$ above the lip line vertically; 
it receives more influence from zygomaticus muscles thus it is difficult to consider LLSAN as an essential muscle in gummy smile treatment. Therefore, it is essential to understand the location and function of these muscles because of their anatomical characteristics, in which different muscles overlap each other and the smiles are made by interaction.

In order to inject BoNT in muscles (LLS, ZM, Zmi, DSN, OO) other than LLSAN, number of points was diversified from 1 to 3 points in each paper. As the number of injection points increases, undesired side effects such as headache, paralysis of facial muscle and twitch may increase. Also, increasing the number of injection points does not seem to lead to an improved outcome. Sucupira and Abramovitz $^{13}$ reported the improvement quantity of $84 \%$ with 1 point injection and Polo ${ }^{12}$ reported the improvement quantity of $98 \%$ with 2 point injection. Suber et al. ${ }^{15}$ reported the improvement quantity of $85 \%$ by conducting 3 point injection. Of course, such phenomenon may come from the fact that there is a difference in the quantity of gummy smile before treatment and number of samples between each paper. Therefore, it is necessary to conduct studies on the relation between the number of points and improvement quantity of gummy smile, and to find a minimum injection point that can achieve maximum effect in the future.

The degree of improvement in gingival exposure before and after the treatment observed to be varyed from 61.1 to $98 \%$ in 8 papers. The evaluation of satisfaction after treatment was conducted in $7 \mathrm{pa}$ pers and presented a high degree of satisfaction, but short-term adverse events were proposed in 3 papers. The treatment longevity was reported for 12 to 36 weeks (Table 3).

Looking into the treatment longevity, the most of studies reported the treatment effects are observed from 2 to 4 days later, maximum effects are observed at 7 to 10 days, and treatment effects last up to 12 to 20 weeks. Polo ${ }^{12}$ noted that the average gingival show had still not returned to baseline values at 24 weeks post-injection. Mazzuco and $\mathrm{Hexsel}^{7}$ demonstrated that there is a prolonged reduction of gingival exposure following several injections of BoNT. It is determined that such phenomenon occurs due to a reduction in muscle volume and contraction capacity followed by temporary paralysis even if BoNT effect disappears.

\section{Discussion}

It is said that aesthetic appearance of a smile is created by harmony between teeth, lip framework, and gingival scaffold. ${ }^{3}$ The lip framework is determined by the activity of various facial muscles, such as LLS, LLSAN, ZM/Zmi. Such muscle plays a role of lifting the upper lip and pulling it toward side when smiling and it creates a smile through interaction with depressor septi nasi muscle, risorius, and orbicularis oris muscle (Fig. 2). Although beautiful smile can be created when there is adequate interaction between muscles, excessive gingival display occurs when excessive muscle capacity is applied to lift upper lip.

The method to improve gummy smile through muscle hyperactivity can largely be divided into surgical and non-surgical method. Various methods have been introduced since Rubinstein and Kostianovsky ${ }^{22}$ have introduced their surgical method and as its limitation the discomfort and side effects followed by the surgery, relapse, and others have been proposed. ${ }^{23}$ In regards to non-surgical method, Polo ${ }^{6}$ has introduced for the first time the method to inject BoNT to muscle around the lip. It has many advantages including less discomfort and side effects after the treatment and non-surgical method.

Although gummy smile treatment method using BoNT has advantages of being safe, reliable, and reversible, it was introduced relatively recently thus there are limitations in that there is not many literatures and research methods and treatment methods of each research differ vastly. Accordingly, the purpose of this study is to provide a summary of treatment method and effects of gummy smile treatment using BoNT injection through literature review and provide a road map for studies on gummy smile treatment using BoNT in the future.

In regards to the measurement of excessive gingival exposure, one of the criteria to determine treatment effect, the measurement method varied 
Table 3. Summary of outcomes in the treatment of excessive gingival display

\begin{tabular}{|c|c|c|c|c|c|c|c|}
\hline Study & $\begin{array}{l}\text { Pre- treat } \\
\text { gingival expos }\end{array}$ & $\begin{array}{l}\text { ment } \\
\text { ure (mm) }\end{array}$ & $\begin{array}{l}\text { Post- treatment } \\
\text { gingival } \\
\text { exposure }(\mathrm{mm})\end{array}$ & $\begin{array}{c}\text { Improvement } \\
\text { degree }\end{array}$ & $\begin{array}{c}\text { Satisfaction } \\
\text { evaluation }\end{array}$ & $\begin{array}{l}\text { Short term } \\
\text { adverse events }\end{array}$ & $\begin{array}{l}\text { Treatment } \\
\text { longevity } \\
\text { (weeks) }\end{array}$ \\
\hline Polo, $2005^{6}$ & \multicolumn{2}{|c|}{$4.2 \mathrm{~mm}$} & $0 \mathrm{~mm}$ & None & none & None & $12-24$ \\
\hline \multirow[t]{3}{*}{ Polo, $2008^{12}$} & \multicolumn{2}{|c|}{$5.2 \mathrm{~mm}$} & $0.09 \mathrm{~mm}$ & $\begin{array}{l}98 \% \text { at } \\
2(\mathrm{~W})\end{array}$ & $\begin{array}{c}\text { Average patient } \\
\text { satisfaction was } 4.66 \\
\text { on a } 5 \text {-point scale }\end{array}$ & $\begin{array}{c}\text { A little } \\
\text { discomfort* }\end{array}$ & $>24$ \\
\hline & Anterior GS & None & None & $\begin{array}{c}96 \% \text { at } \\
20-30 \text { days }\end{array}$ & none & None & $12-20$ \\
\hline & Posterior GS & None & None & $\begin{array}{c}61.1 \% \text { at } \\
20-30 \text { days }\end{array}$ & none & None & $12-20$ \\
\hline \multirow[t]{2}{*}{$\begin{array}{l}\text { Mazzuco } \\
\text { and Hexsel, } \\
2010^{7}\end{array}$} & Mixed GS & None & None & $\begin{array}{c}90.1 \% \text { at } \\
20-30 \text { days }\end{array}$ & none & $\begin{array}{l}\text { One patient- } \\
\text { slightly asym- } \\
\text { metric smile, } \\
\text { One patient- } \\
\text { "sad smile" }\end{array}$ & $12-20$ \\
\hline & $\begin{array}{c}\text { Asymmetric } \\
\text { GS }\end{array}$ & None & None & $\begin{array}{c}71.9 \% \text { at } \\
20-30 \text { days }\end{array}$ & none & None & $12-20$ \\
\hline $\begin{array}{l}\text { Sucupira and } \\
\text { Abramovitz, } \\
2012^{13}\end{array}$ & \multicolumn{2}{|c|}{$3.62 \mathrm{~mm}$} & $0.58 \mathrm{~mm}$ & $\begin{array}{c}84 \% \text { at } \\
2(\mathrm{~W})\end{array}$ & $\begin{array}{c}\text { Average patient } \\
\text { satisfaction was } 9.75 \\
\text { on a } 10 \text {-point scale }\end{array}$ & $\begin{array}{l}\text { Average pain } \\
\text { was } 1.74 \text { on a } \\
10 \text {-point scale }\end{array}$ & $>12$ \\
\hline $\begin{array}{l}\text { Singh et al., } \\
2014^{14}\end{array}$ & \multicolumn{2}{|c|}{$4 \mathrm{~mm}$} & $0.8 \mathrm{~mm}$ & $\begin{array}{c}80 \% \text { at } \\
2(\mathrm{~W})\end{array}$ & $\begin{array}{c}\text { Based on VAS } \\
\text { assessment, all } \\
\text { patients were pleased } \\
\text { with the treatment } \\
\text { results }\end{array}$ & None & 24 \\
\hline $\begin{array}{l}\text { Suber et al., } \\
\qquad 2014^{15}\end{array}$ & Central incisor & $4.25 \mathrm{~mm}$ & $0.75 \mathrm{~mm}$ & $\begin{array}{l}85 \% \text { at } \\
2(\mathrm{~W})\end{array}$ & $\begin{array}{l}\text { Based on } 5 \text {-point } \\
\text { scale, } 13 \text { of } 14 \\
\text { participants were } \\
\text { satisfied with their } \\
\text { results }\end{array}$ & None & 12 \\
\hline $\begin{array}{l}\text { Al Wayli, } \\
2019^{16}\end{array}$ & $7.2 \mathrm{~mm} \pm$ & $=1.77$ & $\begin{array}{l}1.15 \mathrm{~mm} \\
\pm 0.74\end{array}$ & $\begin{array}{c}6.05 \mathrm{~mm} \text { at } \\
12(\mathrm{~W})\end{array}$ & $\begin{array}{l}\text { Based on 5-point } \\
\text { scale, participants } \\
\text { were satisfied with } \\
\text { their results }\end{array}$ & None & $24-36$ \\
\hline \multirow{2}{*}{$\begin{array}{l}\text { Cengiz et al., } \\
2020^{17}\end{array}$} & Group 1 & 4.92 & 1.92 & $\begin{array}{c}3.0 \mathrm{~mm} \text { at } \\
2(\mathrm{~W})\end{array}$ & \multirow{2}{*}{$\begin{array}{c}\text { Based on VAS } \\
\text { assessment, all } \\
\text { patients were pleased } \\
\text { with the treatment } \\
\text { results }\end{array}$} & \multirow{2}{*}{ None } & \multirow{2}{*}{24} \\
\hline & Group 2 & 4.58 & 2.16 & $\begin{array}{c}2.42 \mathrm{~mm} \text { at } \\
2(\mathrm{~W})\end{array}$ & & & \\
\hline \multirow{3}{*}{$\begin{array}{l}\text { Hexsel et al., } \\
\qquad 2020^{18}\end{array}$} & $2.5 \mathrm{U}$ & $\begin{array}{l}3.5 \mathrm{~mm} \\
\pm 1.2\end{array}$ & $\begin{array}{l}1.5 \mathrm{~mm} \\
\pm 1.7\end{array}$ & $\begin{array}{c}2.1 \mathrm{~mm} \text { at } \\
4(\mathrm{~W})\end{array}$ & \multirow{3}{*}{$\begin{array}{l}\text { Survey on the degree } \\
\text { of improvement and } \\
\text { satisfaction were } \\
\text { satisfied with their } \\
\text { results }\end{array}$} & \multirow{3}{*}{ None } & \multirow{3}{*}{12} \\
\hline & $5 \mathrm{U}$ & $\begin{array}{l}4.0 \mathrm{~mm} \\
\pm 1.0\end{array}$ & $\begin{array}{l}0.6 \mathrm{~mm} \\
\pm 1.8\end{array}$ & $\begin{array}{c}3.5 \mathrm{~mm} \text { at } \\
4(\mathrm{~W})\end{array}$ & & & \\
\hline & $7.5 \mathrm{U}$ & $\begin{array}{l}5.2 \mathrm{~mm} \\
\pm 0.8\end{array}$ & $\begin{array}{l}2.2 \mathrm{~mm} \\
\pm 1.4\end{array}$ & $\begin{array}{c}2.9 \mathrm{~mm} \text { at } \\
4(\mathrm{~W})\end{array}$ & & & \\
\hline
\end{tabular}

GS, gummy smile; (W), weeks.

A little discomfort*, Eight subjects reported pain at injection sites and 4 subjects reported twitching at the injection site. One subject experienced headache and 1 subject experienced dizziness. 


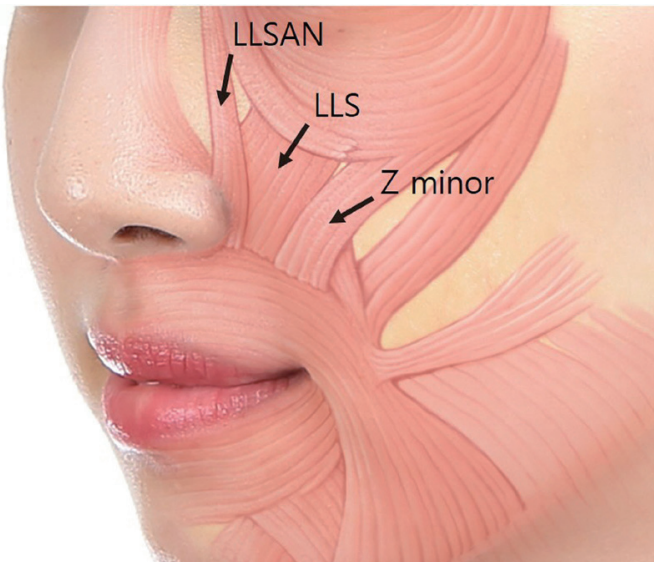

Fig. 2. Main muscle involved in gingival exposure.

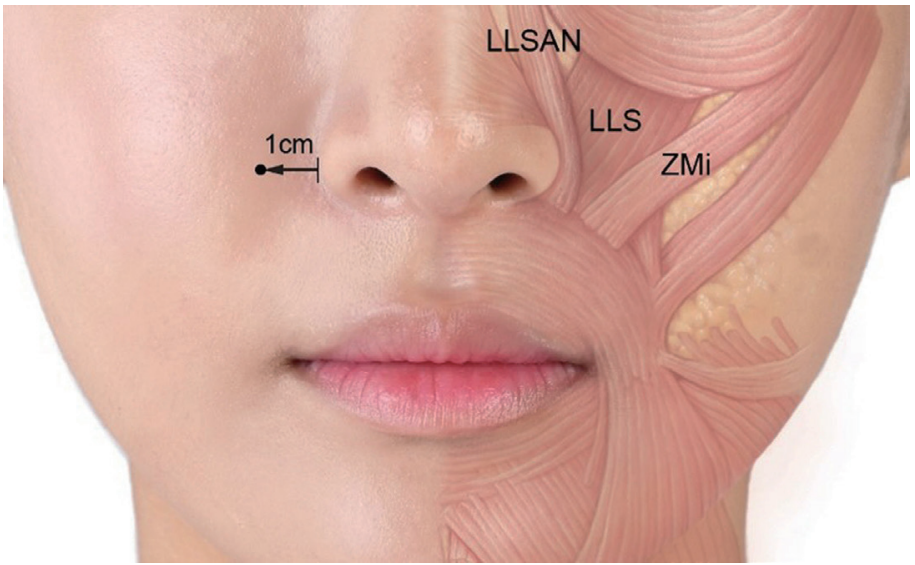

Fig. 3. Recommended injection point for gummy smile treatment. Usually it is located 1 centimeter lateral from ala of nose. for each researcher thus there was controversy in examining the treatment effect. The acquisition of "maximum smile" or "unposed smile" before and after the treatment is an important criteria to examine the treatment effect. Since the patients receiving the treatment know that the goal of treatment is to show less gingival exposure, they may not present maximum smiling for post-treatment smile photo either intentionally or unintentionally different from that of pre-treatment. As it was mentioned by Niamtu, ${ }^{24}$ the only reliable means of controlling smile dynamics would be to accurately stimulate the individual muscles with electrical current (before and after the treatment) with needle electrodes; this would result in controlled, precise, and repeatable contractions. Obviously, this would be a painful situation and almost impossible to duplicate in an awake and conscious patient in the upright position. Therefore, in order to secure the objectivity of gingival exposure quantity before and after the treatment in future studies, study should be conducted with the effort to induce maximum smile.

In terms of the dosages of administered BoNT, similar dose of onabotulinumtoxinA and abobotulinumtoxinA was used and they presented similar improvement effect. However, since abobotulinumtoxin A presents greater efficacy and longer duration of effect, there is an increase in possibility of side effects. ${ }^{25}$ Also, considering the fact that onabotulinumtoxin A is spreading to relatively safe and small area compared to abobotulinumtoxinA, it can be determined that onabotulinumtoxin $A$ is more adequate to be used for facial expression muscle treatment. ${ }^{16}$ Therefore, comparative studies between onabotulinumtoxin A and abobotulinumtoxin A would have significance in future studies.

Kane $^{26}$ treated excessive gingival display through improvement of the nasolabial fold, targeting the LLSAN with $5 \mathrm{U}$ per side. The injection dose was $1 \mathrm{U}$ initially; at 2 to 3 weeks follow-up, the subsequent dose was determined according to clinical response. This is a good and cautious approach that helps to prevent undesirable side effects related to excessive doses or excessive potency of the selected dose for a specific patient. Polo ${ }^{27}$ advised that the dose and injection sites of BoNT should be tailored to the severity of gingival display: 1 injection site and $2 \mathrm{U}$ per side when the gum exposure is inferior $4-5 \mathrm{~mm}$, 1 injection site and $2.5 \mathrm{U}$ per side when the gingival exposure is $5-7 \mathrm{~mm}, 2$ injection sites and $2.5 \mathrm{U}$ injection when it exceeds $7 \mathrm{~mm}$. Therefore, in order to treat gummy smile, the method to inject a different amount based on the quantity of gummy smile rather than injecting fixed amount is necessary. At the moment, the method to inject 2 - 3 U BoNT first and then inject some more through retouching when 
necessary is determined to be more adequate as a safe approach method.

Method to locate injection point was observed differently in each paper. Two papers used electromyography, 1 paper pinpointed the location by feeling the contraction of muscle while smiling with the use of fingers and 6 papers used the method to conduct injection to a certain distance from particular landmark. In order to pinpoint accurate location of muscle, it is of great assistance to use electromyography ${ }^{28,29}$ but the use of electromyography has limitation that it brings about pain and inconvenience. Considering the fact that BoNT spreads $1-2 \mathrm{~cm}$ from the injection point, method to use landmark can be considered as effective. Also, method to use landmark is easily reproducible, can be learned by inexperienced clinicians, is easy to administer. Relevant to such point, Hwang et al. ${ }^{30}$ proposed "Yonsei point" which can deliver BoNT to LLSAN, LLS, and Zmi with 1 point injection through cadaver study. This landmark was identified as the center of a triangle formed by the convergence of the LLSAN, the LLS, and the $\mathrm{Zmi}$ muscles and is located $1 \mathrm{~cm}$ lateral to the ala horizontally and $3 \mathrm{~cm}$ above the lip line vertically in both men and women. Al Wayli ${ }^{16}$ reported that BoNT injected at the Yonsei point was effective in the treatment of gummy smile with little side effect and achieved better results than multiple injections at various sites. (Fig. 3) Cengiz et al. ${ }^{17}$ used $\mathrm{OO}$ site in its study, which can deliver BoNT to LLSAN, LLS, $\mathrm{ZM}, \mathrm{Zmi}$, risorius muscle, orbicularis orris muscle with 1 point injection. The $\mathrm{OO}$ site injection method has the advantage of requiring less dose BoNT than the injection method into LLSAN, but OO muscles are involved in many other basic facial expressions and behaviors (e.g., the animation state needed to harden the lips, such as lip purging, swallowing, sucking, or kissing), so such as muscle weakness and paralysis of these muscles can occur after $\mathrm{OO}$ site injection. Therefore, at present, 1 point injection at "Yonsei point" is considered relatively simple and safe way, and it is thought that a comparative studies of injection points will be needed in the future.

Although most of patients expressed satisfaction toward the treatment in treatment result assessment, short-term discomfort was observed from some patients. Although some patients expressed discomfort at the time of injection insertion and some expressed headache and dizziness after the injection in the study by Polo, ${ }^{12}$ it was mostly a temporary symptom and recovery of symptom was observed within several days. In the study by Mazzuco and Hexsel, ${ }^{7}$ slightly asymmetric smile and sad smile were observed and such discomfort was improved with additional injection. Although such discomfort is temporary phenomenon and it can easily be improved through retouching in follow-up period, side effects that last for several months are observed from some patients. ${ }^{24,31}$ In addition, Chen et al. ${ }^{32}$ reported the temporary horizontal depressing line as an unusual complication. Therefore, Niamtu ${ }^{24}$ and Ahn et al. ${ }^{33}$ asserted that BoNT injection should be conducted by highly experienced practitioners only.

\section{Conclusion}

The purpose of this study was to review the studies on treatment of gummy smile using BoNT injection. For gummy smile treatment, BoNT injection is a non-surgical, reversible, and effective treatment method. As a result of a literature review, gummy smile is not caused solely by the action of the LLSAN muscle, but by the interaction of several muscles such as LLS, ZM, Zmi, DSN, and OO. Also, at present, 1 point injection at "Yonsei point" is reproducible, non-experts are readily applicable, and relatively simple and safe way. Both low and high doses of BoNT presented gummy smile improvement effect. Since high doses of botulinum injection could induce the adverse effect, it is adequate to take a safe approach method where $2 \mathrm{U}$ to $3 \mathrm{U}$ dose is injected first and inject some more as retouching when necessary. Also, it was revealed that the side effects followed by BoNT injection are temporary and treatment effect lasts at least 12 weeks and does not return to its original state even after 24 weeks.

Since this paper has some limitations, I believe that clinically significant result could be acquired when future adequately designed and randomized controlled trials are conducted. 
ttle discomfort $*$, Eight subjects reported pain at injection sites and 4 subjects reported twitching at the injection site. One subject experienced headache and 1 subject experienced dizziness.

\section{Acknowledgements}

This work was supported by the Korea Medical Device Development Fund grant funded by the Korea government (the Ministry of Science and ICT, the Ministry of Trade, Industry and Energy, the Ministry of Health \& Welfare, the Ministry of Food and Drug Safety) (Project Number: KMDF_ PR_20200901_0109).

\section{ORCID}

Yangho Myung https://orcid.org/0000-0002-0428-3496 Keoncheol Woo https://orcid.org/0000-0001-7408-8656

Seong Taek Kim https://orcid.org/0000-0001-9506-5103

\section{References}

1. Humayun N, Kolhatkar S, Souiyas J, Bhola M. Mucosal coronally positioned flap for the management of excessive gingival display in the presence of hypermobility of the upper lip and vertical maxillary excess: a case report. J Periodontol 2010;81:1858-63.

2. Rosenblatt A, Simon Z. Lip repositioning for reduction of excessive gingival display: a clinical report. Int J Periodontics Restorative Dent 2006;26:433-7.

3. Garber DA, Salama MA. The aesthetic smile: diagnosis and treatment. Periodontol 2000 1996;11:1828.

4. de Souza Pinto EB. Relationship between tip nasal muscles and the short upper lip. Aesthetic Plast Surg 2003;27:381-7.

5. Grover HS, Gupta A, Luthra S. Lip repositioning surgery: A pioneering technique for perio-esthetics. Contemp Clin Dent 2014;5:142-5.

6. Polo M. Botulinum toxin type A in the treatment of excessive gingival display. Am J Orthod Dentofacial Orthop 2005;127:214-8; quiz 61.

7. Mazzuco R, Hexsel D. Gummy smile and botulinum toxin: a new approach based on the gingival exposure area. J Am Acad Dermatol 2010;63:104251.

8. Litton C, Fournier P. Simple surgical correction of the gummy smile. Plast Reconstr Surg 1979;63:372-3.

9. Gabrić Pandurić D, Blašković M, Brozović J, Sušić M. Surgical treatment of excessive gingival display using lip repositioning technique and laser gingivectomy as an alternative to orthognathic surgery. J Oral Maxillofac Surg 2014;72:404.e1-11.

10. Rao LB, Sangur R, Pradeep S. Application of Botulinum toxin type A: an arsenal in dentistry. Indian J Dent Res 2011;22:440-5.

11. Pontes HA, Pontes FS, de Oliveira GF, de Almeida HA, Guimarães DM, Cavallero FC. Uncommon foreign body reaction caused by botulinum toxin. J Craniofac Surg 2012;23:e303-5.

12. Polo M. Botulinum toxin type A (Botox) for the neuromuscular correction of excessive gingival display on smiling (gummy smile). Am J Orthod Dentofacial Orthop 2008;133:195-203.

17. Cengiz AF, Goymen M, Akcali C. Efficacy of botulinum toxin for treating a gummy smile. Am J Orthod Dentofacial Orthop 2020;158:50-8.

18. Hexsel D, Dal'Forno T, Camozzato F, Valente I, Soirefmann M, Silva AF, Siega C. Effects of different doses of abobotulinumtoxinA for the treatment of anterior gingival smile. Arch Dermatol Res 2020 Jul 28. doi:10.1007/s00403-020-02096-9.

15. Suber JS, Dinh TP, Prince MD, Smith PD. OnabotulinumtoxinA for the treatment of a "gummy smile". Aesthet Surg J 2014;34:432-7.

19. Fehrenbach MJ, Herring SW. Illustrated Anatomy of the Head and Neck. 2nd ed. Philadelphia; Saunders; 2002.

20. Pessa JE. Improving the acute nasolabial angle and medial nasolabial fold by levator alae muscle resection. Ann Plast Surg 1992;29:23-30.

21. Rubin LR, Mishriki Y, Lee G. Anatomy of the nasolabial fold: the keystone of the smiling mechanism. Plast Reconstr Surg 1989;83:1-10.

13. Sucupira E, Abramovitz A. A simplified method for smile enhancement: botulinum toxin injection for gummy smile. Plast Reconstr Surg 2012;130:726-8.

14. Singh H, Srivastava D, Sharma P, Kapoor P, Roy P. Redefining treatment of gummy smile with Botox- 
a report of three cases. Int J Orthod Milwaukee 2014;25:63-6.

16. Al Wayli H. Versatility of botulinum toxin at the Yonsei point for the treatment of gummy smile. Int J Esthet Dent 2019;14:86-95.

22. Rubinstein A, Kostianovsky A. Cosmetic surgery for the malformation of the laugh: original technique. Prensa Med Argent 1973;60:952.

23. Ellenbogen R. Correspondence and brief communications. Plast Reconstr Surg 1984;73:697-8.

24. Niamtu J 3rd. Botox injections for gummy smiles. Am J Orthod Dentofacial Orthop 2008;133:782-3.

25. Simonetta Moreau M, Cauhepe C, Magues JP, Senard JM. A double-blind, randomized, comparative study of Dysport ${ }^{\circledR}$ vs. Botox ${ }^{\circledR}$ in primary palmar hyperhidrosis. Br J Dermatol 2003;149:1041-5.

26. Kane MA. The effect of botulinum toxin injections on the nasolabial fold. Plast Reconstr Surg 2003;112:66S-72S.

27. Polo M. A simplified method for smile enhancement: botulinum toxin injection for gummy smile. Plast Reconstr Surg 2013;131:934e-5e.

28. Pessa JE, Zadoo VP, Adrian EK Jr, Yuan CH, Aydelotte J, Garza JR. Variability of the midfacial muscles: analysis of 50 hemifacial cadaver dissections. Plast Reconstr Surg 1998;102:1888-93.

29. Klein AW, Mantell A. Electromyographic guidance in injecting botulinum toxin. Dermatol Surg 1998; 24:1184-6.

30. Hwang WS, Hur MS, Hu KS, Song WC, Koh KS, Baik HS, Kim ST, Kim HJ, Lee KJ. Surface anatomy of the lip elevator muscles for the treatment of gummy smile using botulinum toxin. Angle Orthod 2009;79:70-7.

31. Carruthers J, Carruthers A. Botulinum toxin A in the mid and lower face and neck. Dermatol Clin 2004;22:151-8.

32. Chen G, Oranges CM, Giordano S, Huang R, Wang W. Horizontal animation deformity as unusual complication of neurotoxin modulation of the gummy smile. Dermatol Online J 2019;25:13030.

33. Ahn BK, Kim YS, Kim HJ, Rho NK, Kim HS. Consensus Recommendations on the Aesthetic Usage of Botulinum Toxin Type A in A sians. Dermatol Surg 2013;39:1843-60. 


\section{보툴리눔 독소를 이용한 치은과다노출증의 치료 고찰}

명양호 대학원생, 우건철 전문의, 김성택* 교수

연세대학교 치과대학 구강내과학교실

아름다운 미소는 좌우 대칭을 이루며 2 - $3 \mathrm{~mm}$ 치은을 보이는 상태를 일컫는다. 과다한 치은노출은 “거미 스마일”로 불 리며 미적 장애로 인식되어 왔는데 원인으로는 지연맹출, 상악의 과도한 수직성장, 윗입술의 과도한 움직임 또는 짧은 윗 입술로 등으로 보고되어왔다. 한편 클로스트리디움 보툴리눔 세균에서 생성된 외독소인 보툴리눔 독소는 투여된 부위의 신경말단에서 아세틸콜린의 유리를 막아서 근육 수축을 약화시켜 윗입술 과잉 운동으로 인한 치은과다노출증의 새로운 치료법으로 주목 받고있다. 현재까지 입술 주변 근육에 보툴리눔 독소를 주입하는 방법에 대한 많은 연구가 있었지만 아 직 표준화 된 연구 방법과 치료 방법이 없어 치료 효과에 대한 논란이었다.본 종설의 목적은 이러한 지난 과거의 연구들 에서 적응증을 선택하기 위한 요소 및 보툴리눔 독소 치료의 효과를 분석하고자 한다. 특히 치은과다노출증에서 보툴리 눔 독소 주사의 최적의 용량과 최적의 주사부위를 제시하고자 하였다.

(구강회복응용과학지 $2021 ; 37(2): 61-72$ )

주요어: 치은과다노출증; 입술; 보툴리눔독소; 성형; 심미; 치은절제술 